\title{
Appropriate Entrepreneurship Education: A Tool for Women Entreprenuers in Southeast Region of Nigeria
}

\section{Onuorah Unoma C}

\author{
School of Agriculture \& Home Economics, \\ Federal College of Education (Technical) Umunze, \\ Anambra State, \\ Nigeria. \\ Oliobi Jane I. \\ School of Science Education, \\ Federal College of Education (Technical) Umunze, \\ Anambra State, \\ Nigeria.
}

\author{
Doi:10.5901/ajis.2013.v2n6p185
}

\begin{abstract}
The paper was determined on Appropriate Entrepreneurship Education: A tool for women entrepreneurs for the development of Southeast Region of Nigeria. The study adopted a survey research design. The population consisted of 1.2 million comprising of women entrepreneurs. Proportionate stratified random sampling was used in determining the sample size, where the elements were drawn randomly from each stratum in such a way that the relative parent proportions of the strata in the resultant sample were the same as in the parent's population. Therefore the sample size of 1,200 was determined by sampling women from each of the different state in Nigeria. 33 items Questionnaire was used for data collection. Data collected were analyzed using frequency, and mean. The findings include appropriate entrepreneurship education objective for women entrepreneurship in southeast Nigeria and content of entrepreneurship education as a tool for women entrepreneurship in the southeast Nigeria. Recommendations on appropriate entrepreneurship education objectives and content as a tool for women entrepreneurship in Nigeria were made based on the research findings.
\end{abstract}

Keywords: Education, entrepreneurship, women, empowerment, southeast Nigeria

\section{Introduction}

Today women are at the neck of entrepreneurship empowerment, which is very necessary in this present day to increase development necessary to put to stop underemployment by individuals. Women need entrepreneurship education to improve the standard of their entrepreneurship and this will on the other way improve the regional development. According to Onuorah and Olikagu (2011) women both in urban and rural areas have been taking increasing interest in generating activities, self employment and entrepreneurships. Most women belong to Agricultural industrial production, traditional activities like knitting, cream making, soap, pickle production among others, and also nontraditional activities like catering services, beauty salon, gym, clothing production among others. Rijan in Onuorah and Olikagu,(2011) stated that more are coming forward to set up enterprises. It was observed that most of these women even both some of the educated ones, lack 
entrepreneurship education that will enable self reliant employment. And a lot do not have even basic education which will help them to have a wider knowledge in their trade. It is necessary that whether educated or not, entrepreneurial education is needed to equip individuals for creative problem solving and innovation in the course of the entrepreneurship (Igbo 2009). Therefore entrepreneurship according to Gana (2001), is the willingness and ability of an individual to seek out investment opportunities in an environment and be able to establish and run successfully, based on the identified opportunities. Hisrich and peters (2002) viewed entrepreneurship as the dynamic process of creating incremental wealth. Esomonu (1998) in his own way, viewed entrepreneurship as a clear manifestation of effective manipulation of human intelligence as demonstrated in creative performance.

Entrepreneurship Education therefore, according to Igbo (2009) 'is the processes of acquiring the knowledge, attitudes and skills of entrepreneurship. Education according to Thompson (1998) is a process of teaching, training, and learning specifically in schools or colleges to improve knowledge and develop skills. Therefore Education stands as a holistic tool for developing the individual, mentally, physically, morally, characteristically as well as a catalyst in increasing the economic development of a place, through self reliance, efficiency and national consciousness, acquisition of competence necessary for self reliance. Therefore if women should be held into entrepreneurship education before starting up or along their entrepreneurship, will improve their standard as well as sky rot the economic development of the area.

Entrepreneurship education will provide meaningful education for self reliant, and encouragement to profit and self independent stimulate industrial and economic growth of rural and less developed areas (Osuala 2004) and among others. Practically these days we can see that women struggle a lot to keep themselves reliant with one occupation or the other, than men. This may be because women have natural feature and quality in them than men. According to Oprah in Onuorah and Olikagu (2011), Women have more nerve cells in certain areas, they transfer data faster due to large corpus corllusum making it easier for increase flexibility and multitasking, gray matter (area of thinking) in women are $55.4 \%$ and $50.8 \%$ in men. Though male's brain are larger by $10 \%$. In view of this, women have the characteristic to learn and will perform better when obtain certain knowledge or being educated for a particular task.

Therefore, women taking a decision to be an entrepreneur must need a broad appropriate entrepreneurship education like this study to succeed. Women especially the rural women need to be empowered with entrepreneurship education both spiritually, physically and economically. According to oprah in Onuorah and olikagun stated that Nigeria and the world today, a few women posed some challenges to prove that women have innate tendencies of resourceful technical skills (education) in them. According to Oprah in Onuorah and Olikagu (2011) there are women billionaires who employed many people and contribute to the economy up to 3 trillion. Oprah revealed that $47.7 \%$ of private companies are owned by women. This immensely contributes to the millennium development goals. Yet there are many who do not have these potentials in them and suffer a lot because they lack the skills. In view of this fact, they researchers were touched to study on the appropriate entrepreneurship education as a tool for women entrepreneurs. It is touching that most women are very serious using the whole day, energy to engage in a particular trading task, yet at the end most of them still find it difficult to feed, and those who are able to feed, decline in their in their trading and could not maintain their entrepreneurship. These form the basis why this studies Entrepreneurship education: A tool for women entrepreneurship development for southeast Nigeria.

\section{Purpose of the Study}

The main purpose of this study is to determine the appropriate entrepreneurship education: a tool 
for women empowerment in Nigeria Specifically the study is intended to:

1. Identify the appropriate entrepreneurship education objectives for women entrepreneurship in southeast Nigeria.

2. Identify the content of entrepreneurship education for women entrepreneurship in southeast Nigeria.

This study sort answers to the following research questions:

1. What are the appropriate entrepreneurship education objectives for women entrepreneurs in southeast Nigeria?

2. What are the content of entrepreneurship education for women entrepreneurs in south east of Nigeria?

\section{Methodology}

They study utilized a survey design to collect relevant information for the study. It was focused on the people, their opinion, motivation, attitude and behaviour. This was to collect relevant information on analysis of the selected information for appropriate entrepreneurship education. It was calculated from answers elicited from respondents through questionnaires. The study was carried out among five states in the southeast Nigeria comprising of Anambra state, Ebonyi State, Enugu State, Abia state, and Imo state. These states have their local government areas that accommodate all tribes and communities in Nigeria. Southeastern states remained study area since relevant information used on the analysis of the study was obtained.

The population for the study comprised of Anambra with two hundred and fifty thousand $(250,000)$ women entrepreneurs, Abia state with two hundred and ten thousand $(210,000)$ women entrepreneurs, Eboyi with two hundred and ten thousand $(210,000)$ entrepreneurs, Enugu state with three hundred and seventy $(270,000)$ entrepreneurs and Imo state with three hundred and sixty thousand $(260,000)$ entrepreneurs Their actual population comprised a total number of one million two hundred thousand $(1,200000)$, respondents. The population of each of the state was their different major markets (source: market offices).

The sample size was determined using proportionate stratified random sampling. Where the major markets in each state were sampled and entrepreneurs randomly sampled were one thousand two hundred. Therefore the total sample size for the study was 1,200.

The instruments for data collection were structured questionnaire. The questionnaire items were produced based on the information collected from the review of related literature. The questionnaire was made up of two sections A - B with thirty three (33) items on a five point scale of strongly agree, agree, undecided, disagree and strongly disagree with assigned scores of 5, 4, 3,2 and 1 respectively. The instrument was subjected to face validation by making copies of the initial draft of the questionnaire. This was given to three experts in the field of Education of the tertiary Institution in Anambra state Federal college of Education (Technical) Umunze who critically examine the items included with the specific purpose of the study and made useful suggestions that improved the quality of the instrument. Their recommendations, advice, suggestion and observations were used to review the questionnaire items. To determine the reliability of the instrument, the questionnaire item was administered to ten entrepreneurs in Delta state. This was to ensure that the respondents used in the reliability testing were excluded from the study sample. Their responses was subjected to reliability test using Cronbach alpha coefficient which result was 0.85 and was considered reliable for it to be used in collecting data for the study.

Data collection and analysis techniques: One thousand, two hundred $(1,200)$ questionnaires were administered by hand to the respondents by the researcher with the help of research assistants in each major market in the state. However, one thousand $(1,000)$ were returned. Frequency counts and mean were used to analyze the data collected. Any item with a 
mean score of 3.50 and above was regarded as agreed. Similarly, any item scored below 3.50 was regarded as disagreed.

Findings: The following findings were made.

In table one, there were eighteen entrepreneurship education objectives that were accepted as a tool for women entrepreneurs in southeast Nigeria.

Table two was fifteen content of appropriate entrepreneurship education that accepted for as a tool for women entrepreneurship education in southeast Nigeria. See tables below.

Table 1. Mean Responses on the appropriate entrepreneurship Education objectives as a tool for women entrepreneurs in southeast Nigeria.

\begin{tabular}{|c|c|c|c|}
\hline S/No. & The women should be able to: & $\mathrm{X}$ & Remark \\
\hline 1 & Explain the concept of entrepreneurship education & 4.38 & Agreed \\
\hline 2 & $\begin{array}{l}\text { State the importance of entrepreneurship education to women } \\
\text { entrepreneurs }\end{array}$ & 4.33 & Agreed \\
\hline 3 & $\begin{array}{l}\text { State the types of women entrepreneurs and their } \\
\text { entrepreneurship/education }\end{array}$ & 4.31 & Agreed \\
\hline 4 & State the use of entrepreneurship education services & 4.01 & Agreed \\
\hline 5 & I dentify available entrepreneurship education practices & 3.98 & Agreed \\
\hline 6 & $\begin{array}{l}\text { State the importance of knowledge of entrepreneurship Education } \\
\text { for entrepreneurs }\end{array}$ & 4.21 & Agreed \\
\hline 7 & $\begin{array}{l}\text { State if self entrepreneurship education knowledge can keep } \\
\text { Entrepreneurs standard }\end{array}$ & 3.86 & Agreed \\
\hline 8 & $\begin{array}{l}\text { State appropriate entrepreneurship education services available to } \\
\text { entrepreneurs }\end{array}$ & 3.94 & Agreed \\
\hline 9 & Avoid fake words which are barriers to good entrepreneurship & 4.19 & Agreed \\
\hline 10 & state what entrepreneurship education & 4.60 & Agreed \\
\hline 11 & describe the problem of lack of entrepreneurship education & 4.58 & Agreed \\
\hline 12 & state method of contacting entrepreneurs & 4.67 & Agreed \\
\hline 13 & state how to prevent neglect of entrepreneurship education & 4.56 & Agreed \\
\hline 14 & $\begin{array}{l}\text { state the economic impact of appropriate entrepreneurship } \\
\text { education }\end{array}$ & 3.82 & Agreed \\
\hline 15 & $\begin{array}{l}\text { state how to care for entrepreneurs with appropriate } \\
\text { entrepreneurship education knowledge }\end{array}$ & 4.27 & Agreed \\
\hline
\end{tabular}

The respondents accepted all the items in table 1 . This showed that the respondents strongly agreed with all the items as the appropriate entrepreneurship education objectives as a tool for women entrepreneurs in southeast Nigeria.

Table2. Mean response on content of appropriate entrepreneurship education as a tool for women entrepreneurs in southeast Nigeria

\begin{tabular}{|clcc|}
\hline S/No. & $\begin{array}{l}\text { content of appropriate entrepreneurship education } \\
\text { should involve the following: }\end{array}$ & $\mathbf{X}$ & Remark \\
\hline 1 & entrepreneurship characteristics & 4.48 & Agreed \\
2 & functions of entrepreneurship education & 4.22 & Agreed \\
3 & features of entrepreneurs & 4.09 & Agreed \\
4 & creative skills and competencies for success of entrepreneurs & 4.03 & Agreed \\
5 & Accounting and financial competencies & 4.02 & Agreed \\
6 & Planning a trade & 4.32 & Agreed \\
\end{tabular}




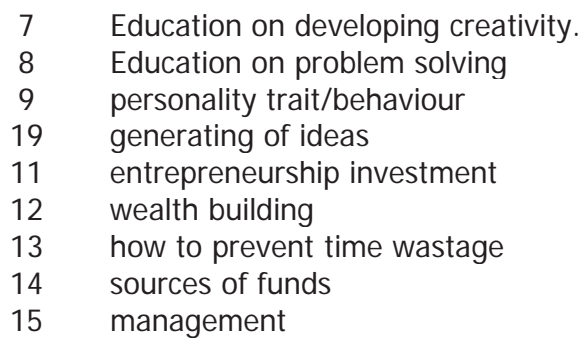
4.15
Agreed
4.34
4.07
3.94
4.29
Agreed
Agreed
Agreed
4.38 Agreed
4.49 Agreed
4.43 Agreed
4.51 Agreed

The respondents accepted items in table 2. This shows that respondents agreed that all items are content of appropriate entrepreneurship education as a tool for women entrepreneurs in southeast of Nigeria.

\section{Discussion}

The study appropriate entrepreneurship education as a tool for women entrepreneurs in southeast Nigeria has been observed as sources of information for any individual to have standard entrepreneurs for economic development. The findings were in line with the views of Osuala 2004) which states that entrepreneurship education will provide meaningful education for self reliant, and encouragement to profit and self independent, stimulate industrial and economic growth of rural and less developed areas. Women need good entrepreneurship education information to improve their skill, attitudes and knowledge of their entrepreneurship. According to Onuorah and Olikagu (2011) women both in urban and rural areas have been taking increasing interest in generating activities, self employment and entrepreneurship. There exist poor conditions of entrepreneurs in southeast Nigeria. This is due to the consequences of non entrepreneurship education activity that can promote entrepreneurship. Igbo (2009) identified that entrepreneurial education is needed to equip individuals for creative problem solving and innovation in the course of the entrepreneurship. Therefore entrepreneurs everywhere still face formidable obstacles to good entrepreneurship. This is due to lack of entrepreneurship education and that is why entrepreneurship education is highly important to entrepreneurs. Women entrepreneurs therefore needed appropriate entrepreneurship objectives and content which is among the content of this study. This study revealed that women needed content of appropriate entrepreneurship education and objectives as facilities to enable them obtain knowledge, attitude and practices that will prevent them from failure. Therefore women needed knowledge of appropriate entrepreneurship education services and should posses and practice entrepreneurship education skills. The study provided the objectives and content of appropriate entrepreneurship education that will equip women with the knowledge, attitude and practice to prevent failure and reposition entrepreneurship to every individual especially the women who were the target of this study.

\section{Conclusion}

The findings of this study, showed that women have been having problems with their entrepreneurship especially on the education which is the main. The needed entrepreneurship education objectives and content like this study to educate women on knowledge, attitude and practice of entrepreneurship among women in southeast of Nigeria. Therefore women will through this study correct their wrong attitudes to entrepreneurship and other ill practices of entrepreneurship to prevent failure. 


\section{Recommendations}

From the findings of this study, the following recommendations were made. The Government of Southeast Nigeria should:

- Improve knowledge, attitudes, skills and behaviours of women entrepreneurship education through schools magazines, mass media, and posters with the entrepreneurship education education from this study.

- women friendly services, women centers, entrepreneurship facility programs, private sector initiatives and social marketing can be linked with the findings from this study.

- Market based programs about entrepreneurship education should be made available to women

\section{References}

Anambra State of Nigeria; State Economic Empowerment \& Development 2nd Edition

Booth, A .L and Dennis J.S. (1996) Acquiring skills: Market failure, their Symptoms and policy responses Canbriage University press

Esomonu N.P(1998) The Essentials of Enterpreneurship Educatio in Technology, Sciience and Arts. Umunze Research and Publication Technical Unit, College of Education (Technical)Federal office off Statistic FOS, (1999) NEEDS: Abuja Communication Development Incorporated.

Forum and United Nations Development (2003) Mellinium Development goals.

http://www.hks.harvard.edu/m-rchg/csrpublications/other-nelson-bud.

Gana , J.S.S (2001) Entrepreneurship: Kaduna J ofegan Associates. Hasty, R and Readon, J (1997) Retail Management: Boston I rwin McGraw=hill.

Hisrich R.D and peters M.P (2002) Entrepreneurship: Fifth Edition Singapore: MacGraw-Hill Higher Education

Homby A.S. (2000) Oxford Advance Learners Dictionary Sixth Edition, New York Oxford University press

Igbo.C.A. (2009) Entrepreneurship Education, Wealth creation Strategies. Great Express Publishers Ltd Nsukka Nigeria.

Onuorah U.C and Olikagu I.A (2011) Technical Skill Development needs of Women Entrepreneurs for Industrial Development in Nigeria. JONATT (Journal of National Association of Teachers of Technology) vol. 8 No. $1 \& 22011$

Osuala.E. C (2004) Principles and methods of Business and computer Education Enugu; Cheston Agency Ltd.

Women entrepreneur-qualities...20-I EO- SAMMY/DOWNloads/entreskills.Ht 